\title{
Characteristics of Okra under Different Process Pretreatments and Different Drying Conditions
}

\section{Adesoji Matthew Olaniyan* and Bamidele David Omoleyomi}

Department of Agricultural and Biosystems Engineering, Faculty of Engineering and Technology, University of Ilorin, P. M. B. 1515, Ilorin 240003, Kwara State, Nigeria

\begin{abstract}
Okra (Abelmoschus caillei) is a vegetable crop that is popular in the tropical region because of its easy cultivation, dependable yield, adaptability to varying weather conditions and resistance to diseases and pests. Apart from its high vitamin B and folic acid contents, okra is said to be very useful against genito-urinary disorders, spermatorrhoea and chronic dysentery while also used in curing ulcers and hemorrhoids. This vegetable crop is seasonal and highly perishable in its natural state after harvest resulting in huge postharvest losses during the production season and extreme scarcity in the off-season. According to past research, drying has demonstrated promising results in preventing postharvest losses and prolonging shelf lives of fruits and vegetables. This study was conducted to investigate the effects of osmotic dehydration process pretreatment and drying temperature on drying rate and quality attributes of okra. A $2 \times 3 \times 4$ factorial experiment under a randomized complete block design was used for the experimental design and the drying process was carried out using a temperature-controlled dryer that has been designed and built prior to this study. Two levels of osmotic solution concentration ( 40 and $60^{\circ} \mathrm{Brix}$ of sucrose), three levels of osmotic process duration $(60,120$ and $180 \mathrm{~min})$ and four levels of drying temperature (50, 60,70 and $80^{\circ} \mathrm{C}$ ) were considered with each trial being carried out in triplicates. The quality attributes investigated included: ash content, crude fibre, crude fat, crude protein, bulk density, least gelation concentration and water absorption capacity. Results showed that drying rate, crude fibre, crude fat, crude protein, bulk density and least gelation concentration increased while ash content and water absorption capacity decreased with increase in drying temperature and osmotic solution concentration. However, drying rate and all the quality parameters increased with increase in drying temperature, osmotic solution concentration and osmotic process duration.
\end{abstract}

Keywords: Drying conditions; Drying rate; Osmotic dehydration; Okra (abelmoschus caillei); Process pretreatments; Quality parameters

\section{Introduction}

Okra is a vegetable crop that belongs to the genus Abelmoschus, family Malvaceae and has two main species: Abelmoschus esculentus (L.) Moench and Abelmoschus caillei (A. Chev.) Stevels [1]. Okra (Figure 1) has been a popular vegetable crop in the tropics because of its ease of cultivation, dependable yield, adaptability to varying moisture conditions and resistance to diseases and pests. The crop is suitable for cultivation as a garden crop as well as on large commercial farms. Okra is the most important fruit vegetable crop and a source of calorie $(4550 \mathrm{kcal} / \mathrm{kg})$ for human consumption. It ranks first before other vegetable crops [2]. As an annual crop, it is one of the most commonly grown vegetable crops in the tropics. Okra is among the most heat and drought-tolerant vegetable species, but severe frost can damage the pods. Okra cultivation and production has been widely practiced because of its importance to the economic development and can be found in almost every market in Africa.

Basically, drying process is a heat and mass transfer phenomenon where water migrates from the interior of the drying product to the surface from where it evaporates. In this process, according to Mohammed et al. [3], the microorganisms that destroy food require moisture to live. In addition to preservation, dehydration reduces product weight and volume by significant amounts and improves the efficiency of product transportation and storage. Mohammed et al. [3] studied the drying characteristics of Okra under different solar dryers in order to evaluate the drying efficiency and qualities of dried okra. In the study, okra was treated by $1.0 \%$ sodium carbonate at boiling point for $3 \mathrm{~min}$ under different drying systems and flow rates of air of 0.075 , 0.149 and $0.249 \mathrm{~m}^{3} / \mathrm{s}$ at the same time. The result obtained showed that the best quality was achieved by using indirect dryer for drying okra at air flow rate of $0.075 \mathrm{~m}^{3} / \mathrm{s}$. Result also showed that the drying efficiency was decreased as the moisture content of okra was reduced.

Roman \& Hensel [4] investigated the effect of air temperature and relative humidity on the thin-layer drying of celery leaves (Apium graveolens var secalinum). In the investigation, thin-layer drying of celery leaves was studied under different conditions of air temperature and relative humidity ranging from $20-50^{\circ} \mathrm{C}$ and $10-60 \%$ respectively

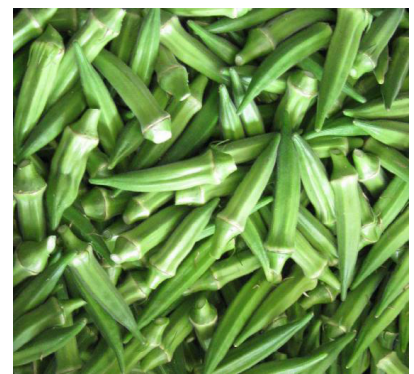

Figure 1: Freshly harvested okra fruits

*Corresponding author: Adesoji Matthew Olaniyan, Department of Agricultural and Biosystems Engineering, Faculty of Engineering and Technology, University of Ilorin, P. M. B. 1515, Ilorin 240003, Kwara State, Nigeria, E-mail: amolan397@hotmail.com

Received April 02, 2013; Accepted May 07, 2013; Published May 15, 2013

Citation: Olaniyan AM, Omoleyomi BD (2013) Characteristics of Okra under Different Process Pretreatments and Different Drying Conditions. J Food Process Technol 4: 237. doi:10.4172/2157-7110.1000237

Copyright: (c) 2013 Olaniyan AM, et al. This is an open-access article distributed under the terms of the Creative Commons Attribution License, which permits unrestricted use, distribution, and reproduction in any medium, provided the original author and source are credited. 
using a through-flow laboratory dryer. Result showed that both air temperature and relative humidity had effect on the drying time with the effect of the former being more pronounced while that of the latter was practically negligible at $50^{\circ} \mathrm{C}$. Result also showed that the color of the dried leaves did not significantly change at temperatures between 20 and $40^{\circ} \mathrm{C}$ but the color was negatively affected at $50^{\circ} \mathrm{C}$.

Agarry and Owabor [5] studied the effects of temperature, solute concentration, size diameter and process time on osmotic dehydration of okra in sucrose solution. They used Response Surface Methodology (RSM) under Central Composite Rotatable Design (CCRD) for the experimentation while optimizing the osmotic dehydration process for water loss and solutes gain. Results showed predicted optimized water loss and solute gain of $39.78 \%$ and $10.16 \%$ respectively at solute concentration, solution temperature, sample size diameter and process time of $49.28(\% \mathrm{w} / \mathrm{w}), 40.79^{\circ} \mathrm{C}, 15 \mathrm{~mm}$ and $4.49 \mathrm{~h}$ respectively. Result also showed that at the predicted optimum condition, the corresponding observed water loss and solute gain were 38.87 and 10.65 (g/100 g initial sample) respectively.

Taiwo et al. [6] studied the influence of osmotic agents and pretreatment methods on mass transfer and product characteristics of strawberry. The investigation included the impact of different pretreatment methods, osmotic solutions and osmotic conditions on some physical characteristics of strawberry. Result showed that highest water loss was obtained in samples treated under vacuum, in a saltsucrose mix or in a high-intensity electric field or under high pressure treatments. Further results showed that the increases in solid gain relative to untreated samples were $96-270,40-160$ and $50-62 \%$ for prefrozen treatment, high pressure treatment and high-intensity electric field treatment respectively.

Singh et al. [7] studied osmotic dehydration kinetics of carrot cubes in sodium chloride solution of concentrations 5, 10 and $15 \%(\mathrm{w} / \mathrm{v})$, solution temperatures of 35,45 and $55^{\circ} \mathrm{C}$, sample-to-solution ratio of 1:4, 1:5 and 1:6 within 240 min duration. Penetration model, Magee model and Azura model were applied to experimental data with Azura model being the best fitted to the experimental data for water loss and solute gain during osmotic dehydration. By interactive technique with a computer programme, effective diffusivities of water and solute were computed with the aid of the analytical solution of Fick's unsteady state law of diffusion. Results showed that the effective diffusivity of water was in the range of $2.6323 \times 10^{-9}$ and $6.2397 \times 10^{-9} \mathrm{~m}^{2} / \mathrm{s}$ while that of solute ranged between $3.1522 \times 10^{-9}$ and $4.6400 \times 10^{-9} \mathrm{~m}^{2} / \mathrm{s}$.

Moreira et al. [8] mathematically modeled the drying kinetics of chestnut (Castanea sativa mill). The drying kinetics were experimentally determined using a pilot-plant scale dryer with a closed air circuit assisted by a heat pump. Experimental conditions such as drying temperature, relative humidity, air velocity and different states of chestnuts were investigated while measured parameters included weight, size and color of the dried product. The results of the experiment showed that higher driving force led to higher drying kinetics when the physical conditions were eliminated. Results also showed that the color of cut dried chestnuts were preserved better and the quality attributes depended on the moisture content of chestnut.

Chenlo et al. [9] studied the mass transfer during osmotic dehydration of chestnut using sodium chloride solutions. Working at three different temperatures of 25,35 and $45^{\circ} \mathrm{C}$, aqueous solution of sodium chloride of concentrations $17.0,22.0$ and $26.5 \% \mathrm{w} / \mathrm{w}$ were used as osmotic media. The output parameters determined included total mass, solids gain, water loss and moisture content while color was determined as a quality parameter for each sample. Empirical model based on Logistic Dose Response (LDR) curves with a diffusion model were employed to achieve the experimental data modelling; the result showed that the LDR model successfully fits the experimental data. Result also revealed that the optimal values of experimental conditions were obtained when a temperature of $25^{\circ} \mathrm{C}$ and a sodium chloride concentration of $22.0 \% \mathrm{w} / \mathrm{w}$ were used.

The demand for okra by the growing population has not been met despite the increase in the production of okra. This is as a result of wastes that come from biological and biochemical activities taking place in this fresh product, inefficient handling and transportation, unfavorable storage conditions, inadequate postharvest handling and poor market outlet. Okra (moisture content $86 \% \mathrm{wb}$ ) is highly perishable in its natural state after harvest; it is seasonal - available during the production season but very scarce and unaffordable during the off-season. This crop contains valuable nutrients to the extent that it should be made available all the year round in a very good postharvest condition.

Drying is the most efficient, reliable and practically feasible methods of postharvest preservation of okra and other highly-perishable fruits and vegetables. Therefore, the main objective of this study was to investigate the effects of some processing parameters on the drying rate and post-drying quality attributes of okra. The specific objectives are: (i) to investigate the effects of osmotic dehydration process as a pretreatment method on drying rate and post-drying quality attributes of okra and; (ii) to investigate the effects of drying temperatures on the drying rate and the post-drying qualities.

\section{Materials and Methods}

\section{Experimental equipment}

The equipment used for this study is an experimental dryer which was designed and built prior to this study. Other apparatus included a refractometer (Model 300002), infrared moisture meter (Model AD4714A), okra slicer, sensitive weighing balance, grinder (Polymix PX-MFC90D), stainless steel knife, thermo-hygrometer, desiccators, sucrose and distil water.

As shown in figures 2 and 3 , the dryer consists of heating chamber having three electrical heating coils of $1.8 \mathrm{~kW}$ each, connected directly

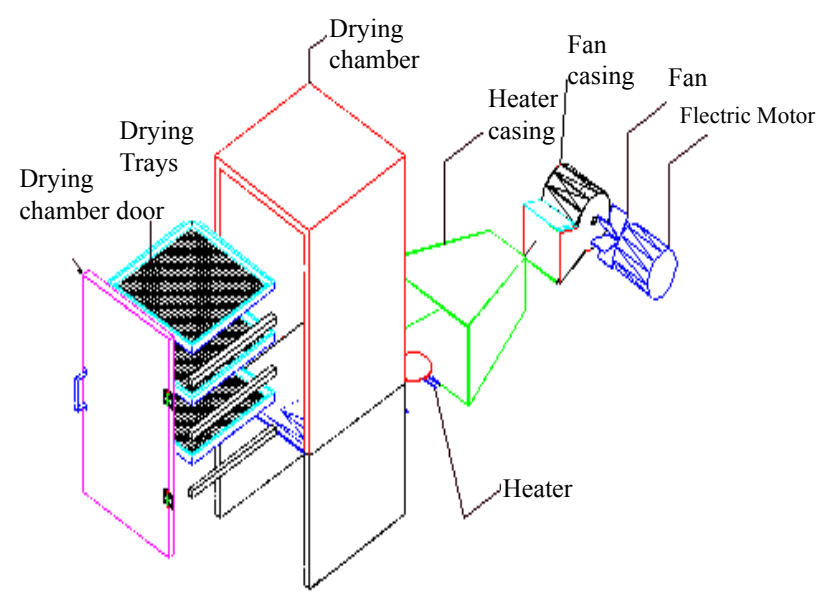

Figure 2: Exploded view of the dryer showing the component parts. 


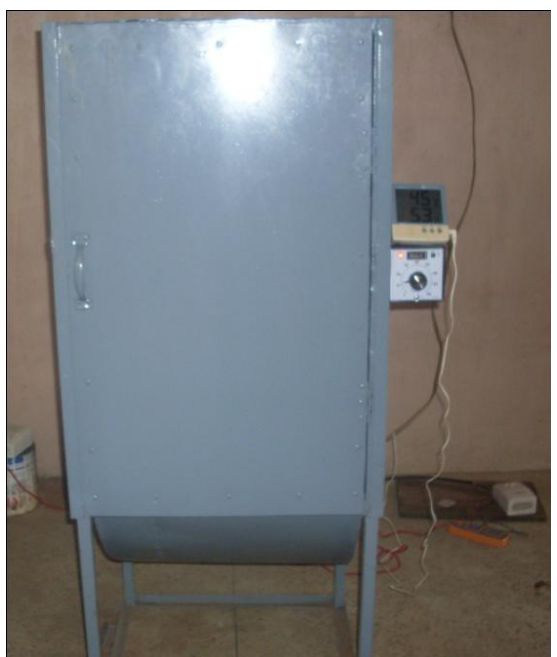

Figure 3: Pictorial side view of the dryer showing the temperature regulator.

to a centrifugal fan of $0.5 \mathrm{hp}$ and drying chamber. The heating coils are connected in series and the whole unit connected to the temperature regulator $\left(0-400^{\circ} \mathrm{C}\right)$ which controls the temperature of the heaters. The drying cabinet measures $50 \mathrm{~cm}$ long, $50 \mathrm{~cm}$ wide and $80 \mathrm{~cm}$ high (with external dimension of $56 \mathrm{~cm} \times 56 \mathrm{~cm} \times 86 \mathrm{~cm}$ ) consisting of three set of trays separated by $15 \mathrm{~cm}$ clearance. The drying chamber is double walled insulated with fiber glass with a thickness of $3 \mathrm{~cm}$. The drying trays having an area of $50 \mathrm{~cm} \times 50 \mathrm{~cm}$ are made from one inch square pipe with expanded metal having an aperture wide enough to allow free flow of heated air.

The heating chamber is trapezoidal in shape with the length of the side touching the drying chamber $60 \mathrm{~cm}$ while the opposite side touching the fan is $20 \mathrm{~cm}$. The length of the chamber is $50 \mathrm{~cm}$ in order to accommodate the heating elements. To ensure that the hot air touches all the products simultaneously the heating chamber opened directly into the drying chamber. To avoid moisture condensation at the top of the dryer vents are provided with the aid of two galvanized pipes of four inch diameter. This was achieved by drilling holes of about $5 \mathrm{~mm}$ diameter for discharge of moisture laden air and for the placement of the thermo-hygrometer probe.

\section{Experimental design}

In order to investigate the effects of the processing parameters on the drying rate and post-drying quality attributes of okra, a $2 \times 3$ $\times 4$ factorial experiment under randomized complete block design (RCBD) was used for the study. The design included two levels of osmotic solution concentration (40 and $60{ }^{\circ} \mathrm{Brix}$ ), three levels of osmotic process duration $(60,120$ and $180 \mathrm{~min})$ and four levels of drying temperature $\left(50,60,70\right.$ and $\left.80^{\circ} \mathrm{C}\right)$. All tests were carried out in triplicates making a total of 72 experimental runs that were individually tested and measured.

\section{Experimental procedure}

Sample pretreatment: Green, mature and freshly-harvested okra pods that were healthy and free from mechanical injuries were purchased from a local farmer within Ilorin metropolis. The okra variety used for this study is known as "Yaya" or "Kogboye" and is commonly grown among farmers in the South-West Zone of Nigeria. Samples were weighed using a top loading balance - Snowrex Counting
Scale (Model SRC 5001, Saint Engineering Ltd., London, UK) with an accuracy of $1 \mathrm{~g}$ and range $0-5000 \mathrm{~g}$.

Okra pods were rinsed in clean water at room temperature and cut with the okra slicer to a thickness of $7 \mathrm{~mm} .100 \mathrm{~g}$ of the sample were weighed and immersed in a hypertonic solution of sucrose of two different concentrations ( 40 and $60^{\circ} \mathrm{Brix}$ - mass ratio of fruit to sucrose was 1:1) for two simultaneous counter-current flows - an exit of water from the product to the solution and a migration of natural solids into the product. Samples were removed from the sucrose solution after separately subjecting them to the three different osmotic process durations $(60,120$ and $180 \mathrm{~min})$. All samples were drained, weighed and checked for sample weight, moisture content and dry solids mass after osmotic dehydration pretreatment.

Drying procedure: The dryer was pre-heated to a temperature of $40^{\circ} \mathrm{C}$ by the means of temperature regulator while the samples were being prepared to ensure stability of the condition of the drying chamber. After arranging the trays in the dryer, the fan was switched on and set to a velocity of $0.5 \mathrm{~m} / \mathrm{s}$ using the fan regulator with the speed measured with the anemometer. The initial condition of the environment and the drying chamber was recorded immediately after loading. $100 \mathrm{~g}$ of samples of okra pretreated with two levels of osmotic solution concentration ( 40 and $60^{\circ} \mathrm{Brix}$ ) for three levels of osmotic dehydration process duration $(60,120$ and $180 \mathrm{~min})$ were weighed and dried at four levels of drying temperature $\left(50,60,70\right.$ and $\left.80^{\circ} \mathrm{C}\right)$ with each experiment carried out in triplicates. The temperature of the exhaust air from the dryer was also measured and recorded. The drying samples were weighed at intervals of $1 \mathrm{~h}$ and drying continued until the desirable moisture contentment of $10 \%(\mathrm{wb})$ was reached.

\section{Output parameters}

Drying rate: Drying rate is the rate of change in moisture with drying time during the drying process. In this study, drying rate was determined by using equation 1 below as:

$$
R=\left(\frac{d M}{d t}\right)=\frac{m_{i}-m_{f}}{t}
$$

where; $\mathrm{R}$ is the drying rate in $\mathrm{g} / \mathrm{h} ; d M$ is change in mass of okra in $\mathrm{g} ; d t$ change in time in $\mathrm{h} ; \mathrm{t}$ is the total time of drying in $\mathrm{h} ; m_{i}$ and $m_{f}$ are the initial and final mass of okra samples respectively in $g$.

Post-drying qualities: The post-drying qualities of okra were determined at the Biochemistry Laboratory of the Nigerian Stored Products Research Institute (NSPRI), Ilorin, using the AOAC [10] standards and Ogungbenle et al. [11] method. The post-drying qualities determined included: crude protein content, crude fat content, crude fibre content, ash content, bulk density, least gelation concentration (LGC) and water absorption capacity (WAC).

Statistical analysis: The data obtained from the experiments for drying rate and post-drying qualities were subjected to the statistical Analysis of Variance (ANOVA) at $95 \%$ confidence level ( $\mathrm{p} \leq 0.05$ ) using the SPSS computer software package. Further analysis by Duncan New Multiple Range Test (DNMRT) was used to compare the means among different levels of each experimental factors.

\section{Results and Discussion}

\section{ANOVA of process variables on drying rate and post-drying qualities}

The result of the statistical analysis of variance (ANOVA) of the data obtained from the experiment is presented in table 1. From the 


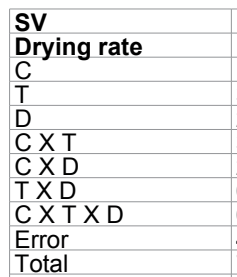

\begin{tabular}{|l|l|}
\hline DF & SS \\
\hline 1 & 8.4 \\
3 & 381 \\
2 & 1.0 \\
3 & 0.5 \\
2 & 1 \\
6 & 3.36 \\
6 & 3.0 \\
48 & 28. \\
71 & 425 \\
\hline
\end{tabular}

\begin{tabular}{l} 
SS \\
8.473 \\
381.657 \\
1.090 \\
0.514 \\
1.194 \\
3.351 \\
3.094 \\
28.000 \\
\hline 25.373
\end{tabular}

\begin{tabular}{|l|}
\hline MS \\
\hline 8.473 \\
127.219 \\
0.545 \\
0.710 \\
0.597 \\
0.558 \\
0.516 \\
0.542 \\
\hline
\end{tabular}

\begin{tabular}{|l|l|}
\hline $\mathbf{F}$ & $\mathbf{P}>\mathbf{F}$ \\
\hline $15.643^{*}$ & 0.000 \\
\hline $234.866^{*}$ & 0.000 \\
\hline 1.006 & 0.373 \\
0.316 & 0.814 \\
1.102 & 0.341 \\
1.031 & 0.417 \\
\hline 0.952 & 0.467 \\
\hline
\end{tabular}

Crude ash

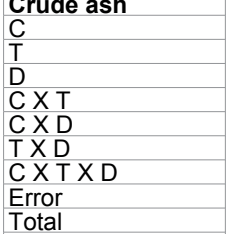

\begin{tabular}{l|l}
\hline Crude fibre & \\
\hline C & 1 \\
\hline T & 3 \\
\hline D & 2 \\
CXT & 3 \\
CXD & 2 \\
\hline TXD & 6 \\
CXT X D & 6 \\
\hline Error & 48 \\
\hline Total & 71 \\
\hline
\end{tabular}

\begin{tabular}{l|l|l} 
Error & 48 & 197.976 \\
\hline Total & 71 & 865.320
\end{tabular}

\begin{tabular}{|l|l|}
\hline Crude fat & \\
\hline C & 1 \\
\hline T & 3 \\
\hline D & 2 \\
\hline CXT & 3 \\
\hline CXD & 2 \\
\hline TXD & 6 \\
\hline CXT X D & 6 \\
\hline Error & 4 \\
\hline Total & 7 \\
\hline
\end{tabular}

\begin{tabular}{|l|l|}
\hline 1 & 8.1 \\
\hline 3 & 17 \\
2 & 5 \\
3 & 0.5 \\
\hline 2 & 0 \\
6 & 0.4 \\
6 & 0.2 \\
\hline 48 & 0.1 \\
\hline
\end{tabular}

\begin{tabular}{l}
8.167 \\
17.27 \\
5.414 \\
0.513 \\
0.150 \\
0.450 \\
0.269 \\
0.139 \\
\hline 32.365
\end{tabular}

\begin{tabular}{|l|l|} 
& \\
\hline 1 & 16.321 \\
3 & 555.959 \\
\hline & 80.667
\end{tabular}

\begin{tabular}{|l|l|}
\hline 8.161 & 2. \\
\hline 5.757 & 1.9 \\
\hline 2.707 & 935 \\
\hline 0.171 & 5 \\
\hline 0.075 & 25 \\
\hline 0.075 & 25 \\
\hline 0.045 & 15 \\
\hline
\end{tabular}

$2.821 \mathrm{E}^{\circ} 3^{*}$
$1.990 \mathrm{E} 03^{*}$

0.000

\begin{tabular}{ll}
$1.990 \mathrm{E} 03^{*}$ & 0.000 \\
\hline $35.607^{*}$ & 0.000
\end{tabular}

\begin{tabular}{|ll}
$935.607^{*}$ & 0.000 \\
\hline $59.070^{*}$ & 0.000
\end{tabular}

$59.070^{*}$

0.000

0.000

$\begin{array}{lll}0.075 & 25.923^{*} & 0.000 \\ 0.045 & 15.524^{*} & 0.000\end{array}$

0.045

$15.524^{*}$

0.000

0.003

\begin{tabular}{|l|l|l|} 
& & \\
\hline 16.321 & 3.957 & 0.052 \\
\hline 85.320 & 44.931 & 0.000 \\
\hline 40.334 & 9.779 & 0.000 \\
\hline 0.565 & 0.137 & 0.937 \\
\hline 0.559 & 0.136 & 0.874 \\
\hline 1.609 & 0.390 & 0.882 \\
\hline 0.322 & 0.078 & 0.998 \\
\hline 4.125 & & \\
\hline
\end{tabular}

\begin{tabular}{l|l} 
& \\
1 & 0.226 \\
3 & 5.658 \\
\hline & 0.234
\end{tabular}

0.226
1.886

\begin{tabular}{|l|l} 
& \\
$7.164^{*}$ & 0.010 \\
$59.895^{\star}$ & 0.000 \\
\hline $3.708^{*}$ & 0.032
\end{tabular}

\begin{tabular}{|l|l|l|}
\hline 0.226 & $7.164^{\star}$ & 0.010 \\
\hline .886 & $59.895^{\star}$ & 0.000 \\
0.117 & $3.708^{*}$ & 0.032 \\
\hline 0.002 & 0.078 & 0.972 \\
\hline .002 & 0.078 & 0.925
\end{tabular}

\begin{tabular}{|l|l|l}
\hline 0.002 & 0.078 & 0.972 \\
\hline 0.002 & 0.078 & 0.925
\end{tabular}

$\begin{array}{lll}0.002 & 0.078 & 0.925 \\ 0.043 & 1.377 & 0.243\end{array}$

Error

$\begin{array}{lll}3 & 0.007 & 0.002 \\ 2 & 0.005 & 0.002 \\ 6 & 0.260 & 0.043 \\ 6 & 0.027 & 0.004 \\ 48 & 1.511 & 0.310 \\ 71 & 7.928 & \end{array}$

$\begin{array}{lll}0.004 & 0.143 & 0.990\end{array}$

Crude protein

\begin{tabular}{|l|} 
Crude protein \\
\hline C \\
\hline T \\
\hline D \\
\hline CXT \\
\hline CXD \\
\hline TXD \\
\hline CXT XD \\
\hline Error \\
\hline Total \\
\hline
\end{tabular}

1

7.928

10

\begin{tabular}{l|l}
11.155 & 11 \\
22.154 & 7.38 \\
23.875 & 11.9
\end{tabular}

11.155
7.385
11.937
0.092
0.053

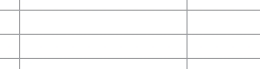

\begin{tabular}{l|l}
$5.710^{*}$ & 0.021 \\
\hline $3.780^{*}$ & 0.016
\end{tabular}

\begin{tabular}{|l|l|}
\hline $5.710^{*}$ & 0.021 \\
\hline $3.780^{*}$ & 0.016 \\
\hline $6.111^{*}$ & 0.004 \\
\hline 0.047 & 0.986
\end{tabular}

0.004

0.973 0.999
1.000

\begin{tabular}{|c|c|c|c|c|c|}
\hline CXTXD & 6 & 0.043 & 0.007 & 0.004 & 1.000 \\
\hline Error & 48 & 93.767 & 1.953 & & \\
\hline Total & 71 & 151.943 & & & \\
\hline \multicolumn{6}{|c|}{ Bulk density } \\
\hline C & 1 & 0.003 & 0.003 & $1.084^{*}$ & 0.303 \\
\hline $\mathrm{T}$ & 3 & 0.070 & 0.023 & $9.825^{*}$ & 0.000 \\
\hline D & 2 & 0.006 & 0.003 & $1.285^{*}$ & 0.286 \\
\hline $\mathrm{C} \times \mathrm{T}$ & $\overline{3}$ & 0.003 & 0.001 & 0.422 & 0.738 \\
\hline$C \times D$ & 2 & 0.005 & 0.003 & 1.074 & 0.350 \\
\hline$T \times D$ & 6 & 0.044 & 0.007 & 3.049 & 0.013 \\
\hline$C \times T \times D$ & 6 & 0.004 & 0.001 & 0.282 & 0.943 \\
\hline Error & 48 & 0.114 & 0.002 & & \\
\hline Total & 71 & 0.249 & & & \\
\hline \multicolumn{6}{|l|}{ LGC } \\
\hline $\mathrm{C}$ & 1 & 23.347 & 23.347 & 3.452 & 0.069 \\
\hline $\mathrm{T}$ & 3 & 181.375 & 60.458 & $8.938^{*}$ & 0.000 \\
\hline D & 2 & 87.250 & 43.625 & $6.450^{*}$ & 0.003 \\
\hline $\mathrm{CXT}$ & 3 & 16.708 & 5.569 & 0.823 & 0.487 \\
\hline$C \times D$ & 2 & 4.694 & 2.347 & 0.347 & 0.709 \\
\hline$T \times D$ & 6 & 47.750 & 7.958 & 1.177 & 0.335 \\
\hline$C \times T \times D$ & 6 & 16.083 & 2.681 & 0.396 & 0.878 \\
\hline Error & 48 & 324.667 & 6.764 & & \\
\hline Total & 71 & 701.875 & & & \\
\hline \multicolumn{6}{|l|}{ WAC } \\
\hline $\mathrm{C}$ & 1 & 0.113 & 0.113 & 2.608 & 0.113 \\
\hline $\bar{T}$ & 3 & 2.846 & 0.949 & $21.927^{*}$ & 0.000 \\
\hline D & 2 & 0.968 & 0.484 & 11.189* & 0.000 \\
\hline $\mathrm{C} \times \mathrm{T}$ & 3 & 0.063 & 0.021 & 0.482 & 0.696 \\
\hline$C \times D$ & 2 & 0.028 & 0.014 & 0.320 & 0.728 \\
\hline$T \times D$ & $\overline{6}$ & 0.134 & 0.022 & 0.518 & 0.792 \\
\hline$C \times T \times D$ & 6 & 0.056 & 0.009 & 0.217 & 0.969 \\
\hline Error & 48 & 2.077 & 0.043 & & \\
\hline Total & 71 & 6.285 & & & \\
\hline
\end{tabular}

*Significantly different at $\mathrm{P} \leq 0.05$.

Table 1: Analysis of variance (ANOVA) of the effect of process variables on drying rate and post-drying qualities of okra: C - osmotic solution concentration; $\mathrm{T}$ - drying temperature; D - osmotic process duration; LGC - least gelation concentration; WAC - water absorption capacity. analysis table, it is clear that the drying temperature was significant on drying rate and all the post-drying quality parameters; osmotic solution concentration was significant on the drying rate and postdrying qualities except crude fiber, least gelation concentrations (LGC) and water absorption capacity (WAC); osmotic process duration was significant on all the post-drying qualities but not on drying rate; no interaction of the process variables was significant on any of the output parameters except crude ash on which all the process variables and their interactions were significant, all at $\mathrm{p} \leq 0.05$. This implies that osmotic solution concentration, osmotic process duration and drying temperature had appreciable effects on the drying rate and post-drying quality attributes of okra. Therefore, while drying okra, these factors must be carefully controlled.

\section{Effect of osmotic solution concentration on drying rate and post-drying qualities}

The effect of osmotic solution concentration on drying rate is shown in figure 4 . The figure showed that, generally, osmotic solution concentration had no appreciable effect on drying rate. However, for drying temperature of $50^{\circ} \mathrm{C}$, drying rate at osmotic solution concentration of $40^{\circ} \mathrm{Brix}$ was higher than that $60^{\circ} \mathrm{Brix}$. As shown in figure 5 , increase in osmotic solution concentration decreased the ash content at all levels of osmotic process duration and drying temperature. Crude fibre slightly increased with increased with increasing osmotic solution concentration from 40 to $60{ }^{\circ}$ Brix (Figure 6) at all drying temperatures and osmotic process duration.

As indicated by figure 7 , values of crude fat obtained at osmotic solution concentration of $40^{\circ} \mathrm{Brix}$ were not different those at $60^{\circ} \mathrm{Brix}$ Implying that osmotic solution concentration did not have effect on the crude fat content of dried okra. Crude protein increased with increasing osmotic solution concentration for all osmotic process duration and drying temperature (Figure 8). Bulk density increased with increasing osmotic solution concentration from 40 to $60^{\circ} \mathrm{Brix}$ for drying temperatures of 50,60 and $80^{\circ} \mathrm{C}$ but decreased with increasing osmotic solution concentration for drying temperature of $70^{\circ} \mathrm{C}$ (Figure

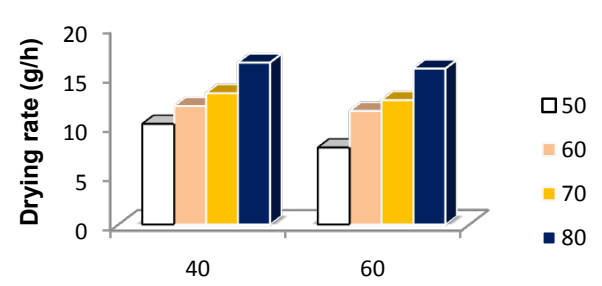

Osmotic solution concentration ( $\left.{ }^{\circ} \mathrm{Brix}\right)$

Figure 4: Effect of osmotic solution concentration on drying rate at different drying temperature for $60 \mathrm{~min}$.

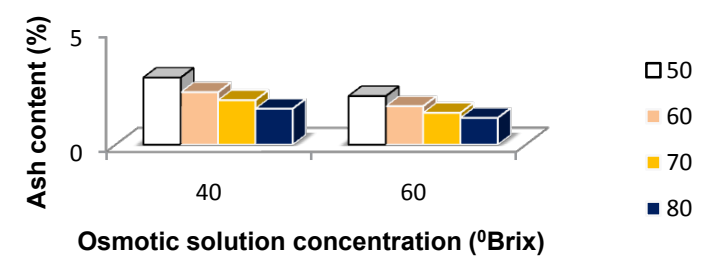

Figure 5: Effect of osmotic solution concentration on ash content at different drying temperature for $60 \mathrm{~min}$. 


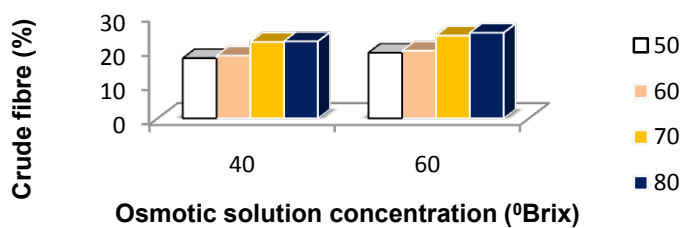

Figure 6: Effect of osmotic solution concentration on crude fibre at different drying temperature for $60 \mathrm{~min}$.

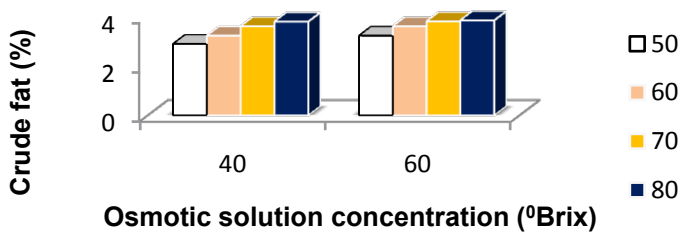

Figure 7: Effect of osmotic solution concentration on crude fat at different drying temperature for $60 \mathrm{~min}$.

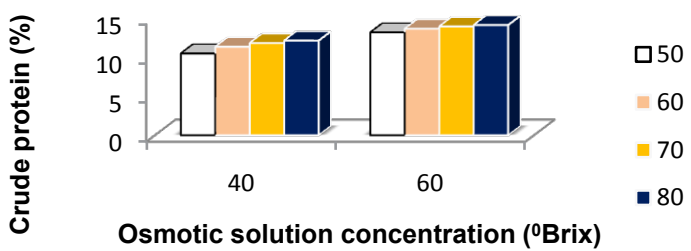

Figure 8: Effect of osmotic solution concentration on crude protein at different drying temperature for $60 \mathrm{~min}$.

9). As seen from figure 10 , LGC at $60^{\circ} \mathrm{Brix}$ was higher, when compared with that of $40^{\circ}$ Brix. From figure 11, it is obvious that increase in osmotic solution concentration from $40-60^{\circ}$ Brix led to increase in WAC.

\section{Effect of drying temperature on drying rate and post-drying qualities}

From table 2, it is obvious that drying rate increased as the drying temperature increased from 50 to $80^{\circ} \mathrm{C}$ at all levels of osmotic dehydration concentration and osmotic dehydration time. This is in agreement with the findings of past researchers such as Mohamed et al. [3]. Duncan's New Multiple Range Test (Table 2) showed that, all levels of drying temperature had effect on drying rate (at $\mathrm{P} \leq 0.05$ ). This implies that increase in the drying temperature from 50 to $80^{\circ} \mathrm{C}$ showed a progressive increase in the drying rate. Ash content decreased as the drying temperature increased from 50 to $80^{\circ} \mathrm{C}$ at all levels of osmotic dehydration concentration and osmotic dehydration time. Furthermore, all levels of drying temperature had effect on ash content (at $\mathrm{P} \leq 0.05$ ). This implies that increase in the drying temperature from 50 to $80^{\circ} \mathrm{C}$ resulted in a progressive decrease in the ash content.

Crude fiber increased with increasing drying temperature for all levels of osmotic dehydration concentration and osmotic dehydration time. Further analysis showed that crude fiber between 50 and $70^{\circ} \mathrm{C}$, 50 and $80^{\circ} \mathrm{C}, 60$ and $70^{\circ} \mathrm{C}, 60$ and $80^{\circ} \mathrm{C}$ were significantly different but, between 50 and $60^{\circ} \mathrm{C}, 70$ and $80^{\circ} \mathrm{C}$ were not significantly different. From the data, the highest value of crude fiber was recorded at $80^{\circ} \mathrm{C}$. Crude fat increased as the drying temperature increased from 50 to $80^{\circ} \mathrm{C}$. Crude fat at 70 and $80^{\circ} \mathrm{C}$ were not significantly different from each other but values at other levels of drying temperature were significantly different with value of crude fat at $80^{\circ} \mathrm{C}$ being the highest. Crude protein and bulk density increased with increasing drying temperature from 50 to $80^{\circ} \mathrm{C}$. The lowest LGC was obtained at $60^{\circ} \mathrm{C}$ which implies that dry okra will get better at $60^{\circ} \mathrm{C}$. The lower the LGC, the better the gelling ability [11]. As the drying temperature increased from 50 to $80^{\circ} \mathrm{C}$, WAC of the dried okra decreased to the minimum value.

Effect of osmotic process duration on drying rate and postdrying qualities

All discussions on the effect of osmotic process duration on drying rate and post-drying qualities are based on table 3 below. Drying rate showed progressive increase (though not statistically significant) with increasing osmotic process duration. Ash content and crude fiber increased as the osmotic process duration increased from 60 to $180 \mathrm{~min}$ at different temperature and for all osmotic solution concentration. Crude fat content was almost the same for all osmotic process durations. Values of crude fat 60 and $120 \mathrm{~min}$ were not significantly different, while the values at 60 and $180 \mathrm{~min}, 120$ and $180 \mathrm{~min}$ were significantly different.

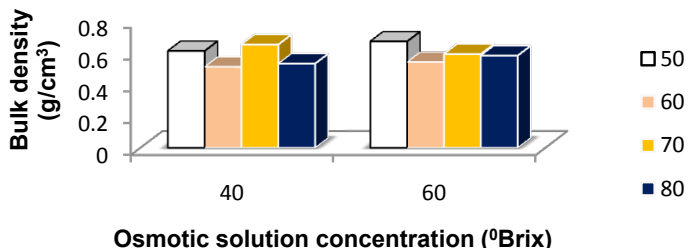

Figure 9: Effect of osmotic solution concentration on bulk density at different drying temperature for $60 \mathrm{~min}$

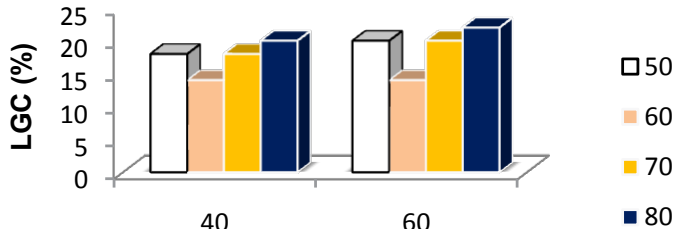

Osmotic solution concentration ( $\left.{ }^{\circ} \mathrm{Brix}\right)$

Figure 10: Effect of osmotic solution concentration on LGC at different drying temperature for $60 \mathrm{~min}$.

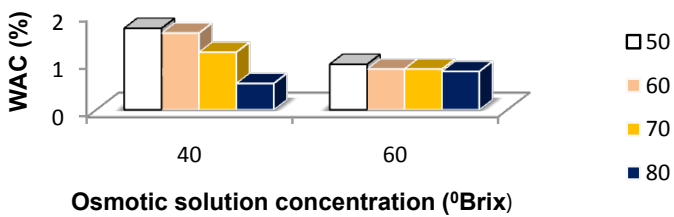

Figure 11: Effect of osmotic solution concentration on WAC at different drying temperature for $60 \mathrm{~min}$ 


\begin{tabular}{|c|c|c|c|c|}
\hline Drying Temperature $\left({ }^{\circ} \mathrm{C}\right)$ & 50 & 60 & 70 & 80 \\
\hline Drying rate $(\mathrm{g} / \mathrm{h})$ & $9.7000^{d}$ & $11.7778^{c}$ & $12.9167^{b}$ & $16.0667^{\mathrm{a}}$ \\
\hline Crude ash (\%) & $2.9122^{\mathrm{a}}$ & $2.5050^{\mathrm{b}}$ & $2.0006^{c}$ & $1.6222^{d}$ \\
\hline Crude fibre (\%) & $18.9267^{\mathrm{b}}$ & $20.2500^{\mathrm{b}}$ & $24.6728^{a}$ & $25.4106^{a}$ \\
\hline Crude fat $(\%)$ & $3.1089^{c}$ & $3.5650^{\mathrm{b}}$ & $3.7339^{a}$ & $3.8439^{a}$ \\
\hline Crude protein (\%) & $11.1022^{b}$ & $11.6572^{a}$ & $12.1878^{a}$ & $12.5739^{a}$ \\
\hline Bulk density $\left(\mathrm{g} / \mathrm{cm}^{3}\right)$ & $0.5929^{a}$ & $0.5362^{b}$ & $0.6111^{a}$ & $0.5466^{b}$ \\
\hline Least gelation concentration, LGC (\%) & $20.0000^{\mathrm{a}}$ & $17.1667^{\mathrm{b}}$ & $20.6667^{a}$ & $21.3333^{\mathrm{a}}$ \\
\hline Water absorption capacity, WAC (\%) & $1.2583^{a}$ & $1.1750^{\mathrm{a}}$ & $0.9833^{b}$ & $0.7417^{c}$ \\
\hline
\end{tabular}

*Means with the same letter are not significantly different but means with different letters are significantly different (at $P \leq 0.05)$ using Duncan's New Multiple Range Test

Table 2: Effect of drying temperature on drying rate and post-drying qualities of okra*

\begin{tabular}{|c|c|c|c|}
\hline Osmotic process duration (min) & 60 & 120 & 180 \\
\hline Drying rate $(\mathrm{g} / \mathrm{h})$ & $12.4417^{\mathrm{a}}$ & $12.6917^{\mathrm{a}}$ & $12.7125^{a}$ \\
\hline Crude ash (\%) & $1.8854^{c}$ & $2.3604^{b}$ & $2.5342^{\mathrm{a}}$ \\
\hline Crude fibre (\%) & $21.0571^{\mathrm{c}}$ & $22.2412^{\mathrm{b}}$ & $23.6467^{a}$ \\
\hline Crude fat (\%) & $3.5042^{b}$ & $3.5446^{b}$ & $3.6400^{\mathrm{a}}$ \\
\hline Crude protein $(\%)$ & $12.5671^{\mathrm{a}}$ & $11.9158^{\mathrm{a}}$ & $11.1579^{b}$ \\
\hline Bulk density $\left(\mathrm{g} / \mathrm{cm}^{3}\right)$ & $0.5846^{a}$ & $0.5638^{a}$ & $0.5668^{a}$ \\
\hline Least gelation concentration, LGC (\%) & $18.2500^{\mathrm{b}}$ & $20.3750^{\mathrm{a}}$ & $20.7500^{\mathrm{a}}$ \\
\hline Water absorption capacity, WAC (\%) & $1.0625^{a}$ & $1.1687^{a}$ & $0.8875^{b}$ \\
\hline
\end{tabular}

*Means with the same letter are not significantly different but means with different letters are significantly different (at $P \leq 0.05)$ using Duncan's New Multiple Range Test.

Table 3: Effect of osmotic process duration on drying rate and post-drying qualities of okra*

Crude protein decreased as the osmotic process duration increased from 60 to $180 \mathrm{~min}$. Values of crude protein at 60 and $120 \mathrm{~min}$ were not significantly different from each other but significantly different from that at that at $180 \mathrm{~min}$. Osmotic process duration had no appreciable effect on bulk density. LGC increased as the osmotic process duration increased from 60 to $180 \mathrm{~min}$. Values of LGC at 120 and $180 \mathrm{~min}$ were not significantly different but significantly different from the value at 60 min which gave the lowest value of LGC. WAC increased with increasing osmotic process duration from 60 to $180 \mathrm{~min}$ with the highest value being at $120 \mathrm{~min}$. WAC is an indication of the dried okra being used as a thickener in liquid and semi-liquids foods as dried okra has the ability to absorb water and swell for improved consistency in food.

\section{Conclusion}

Okra dries faster at a higher temperature as compared to a lower temperature. Osmotic dehydration pretreatment increases the rubbery nature of materials. LGC had the lowest value at $60^{\circ} \mathrm{C}$ implying that dried okra will get better at $60^{\circ} \mathrm{C}$ compared with higher drying temperatures. Ash content can be best preserved in okra by drying at a lower temperature of $50^{\circ} \mathrm{C}$, osmotic solution concentration of 40 ${ }^{\circ}$ Brix and osmotic process duration of $180 \mathrm{~min}$. Based on the result of this study, crude protein, crude fiber and crude fat in dried okra can be maximized by drying at $80^{\circ} \mathrm{C}$ after pretreatment with osmotic solution concentration of $60^{\circ} \mathrm{Brix}$ and osmotic process duration of $180 \mathrm{~min}$. WAC was higher at a drying temperature of $50^{\circ} \mathrm{C}$, osmotic solution concentration of $40^{\circ} \mathrm{Brix}$ and osmotic process duration of 120 min. Further studies should be carried out on the factors that affect the storability of dried okra for long-time storage and preservation. Further studies should also be carried out to investigate the use of sucrose for osmotic dehydration pretreatment vis-à-vis the palatability of dried okra.

\section{References}

1. Siemonsma JS (1982) The cultivation of okra (Abelmoschus spp.), a tropical vegetable, with special reference to the Ivory Coast. Wageningen Agricultura Agricultural University, Wageningen, the Netherland.

2. Babatunde RO, Omotesho OA, Sholotan OS (2007) Socio-economic Characteristics and Food Security Status of Farming Household in Kwara State, North-Central Nigeria. Pakistan Journal of Nutrition 6: 49-58.

3. Mohammed MA, Gamae GR, Keshek MH (2010) Drying Characteristics of Okra by Different Solar Dryers. Misr J Ag Eng 27: 294-312.

4. Roman F, Henshel O (2011) Effect of air temperature and relative humidity on the thin-layer drying of celery leaves (Apium graveolens var. secalinum). Agricultural Engineering International-CIGR Journal 13: 1-11.

5. Agarry SE, Owabor CN (2012) Statistical optimization of process variables for osmotic dehydration of okra (Abelmoschus esculentus) in sucrose solution. Nigerian Journal of Technology 31: 370-382.

6. Taiwo KA, Eshtiaghi MN, Ade-Omowaye BIO, Knorr D (2003) Osmotic dehydration of strawberry halves: influence of osmotic agents and pretreatment methods on mass transfer and product characteristics. Int J Food Sci Tech 28 : 693-707.

7. Singh B, Panesar PS, Nanda V (2008) Osmotic dehydration kinetics of carrot cubes in sodium chloride solution. Int J Food Sci Tech 43: 1361-1370.

8. Moreira R, Chenlo F, Chaguri L, Vázquez G (2005) Mathematical Modeling of the Drying Kinetics of Chestnut (Castanea sativa mill.). Food Bioprod Process 83: $306-314$.

9. Chenlo F, Moreira R, Fernandez-Herrero G, Vázquez G (2006) Mass transfe during osmotic dehydration of chestnut using sodium chloride solutions. J Food Eng 73: 164-173.

10. AOAC (1990) Official Methods of Analysis of the Association of Official Analytical Chemists, $\left(15^{\text {th }}\right.$ ed.). Arlington, Virginia, USA.

11. Ogungbenle HN, Oshodi AA, Oladimeji MO (2002) Effect of salts on the functional properties of benniseed (Sesamum radiatum) seed flour. Int J Food Sci Nutr 53: 5-14. 